\title{
Between-Class Ability Grouping, Cram Schooling, and Student Academic Achievement in Taiwan
}

\author{
Jeng Liua, Cheng-Hsiang Yanga
}

\begin{abstract}
Taiwan government has been executing the educational reform programs for more than two decades. However, the so-called between-class ability grouping which is prohibited by Taiwan government is still found in many places; and Taiwan's cram schools are even more popular and diversified than before. The authors argue that, in addition to individual's socio-economic background, regional characteristics and school attributes also play important roles. Bringing these two factors back in, the causal relationships among ability grouping, cram schooling, and student academic achievement can be analyzed more accurately. Using data from Taiwan Education Panel Survey, the authors' empirical results show that, first of all, in more urbanized area, between-class ability grouping is less popular but cram school participation is wider spread these years. Secondly, the effects of family backgrounds on students' cram school participation are not as critical as they were before. Thirdly, between-class ability grouping and students' performance are positively associated but the internal mechanism still needs further investigation.
\end{abstract}

\section{Keywords}

Academic achievement, regional characteristics, school attributes, between-class ability grouping, cram schooling

It has been over 30 years since compulsory education was executed in Taiwan since 1968. During this time, there have been numerous discussions about students' learning and schools' teaching approaches. Educational reform has debated several issues, and the "between-class ability grouping" is one of the heatedly-debated issues. Supporters' opinions stress that learning with other students of similar academic ability level may help motivate each other and improve academic achievement; whereas, opponents largely assert themselves from the perspectives of equality, cultural capital, and the right to learn.

Although the law has specifically banned between-class ability grouping, what is the actual situation at most schools? As revealed by the results of relevant surveys published by the Humanistic Education Foundation, junior high schools in most areas of Taiwan still group students into classes based on academic ability, and cover it up with different pretexts. As a result, various issues, such as how schools circumvent the law to group students into classes based on ability, whether between-class ability grouping and within-class ability grouping are reflective of regional characteristics and differences, advantages and disadvantages of between-class ability

aTunghai University, Taiwan

\section{Correspondent Author:}

Jeng Liu, Department of Sociology, Tunghai University, No. 1727, Sec. 4, Taiwan Blvd, Taichung, 40704, Taiwan 
grouping, as well as parents' opinions or actual concerns regarding between-class ability grouping, all call for in-depth exploration.

Additionally, it appears that analysis of factors for students' academic achievement shall not discount the cram schooling phenomenon in Taiwan's education environment. Despite the attempt by education reform to alleviate students' academic pressure, create courses related to people's daily activities, and bring school teaching back to normal, it is ironic that cram schooling has become increasingly popular in recent years. Undoubtedly, the increasing popularity of the cram schooling phenomenon cannot be explained by the socioeconomic background of students' family alone. According to the authors' observation, between-class ability grouping and cram schooling are deeply correlated to regional characteristics and school attributes. On the one hand, between-class ability grouping, which has been specifically banned, may be presented differently due to urban, rural, or regional differences in reality. The closer a school is to relevant governing authorities or the more urbanized the school area is, the less likely the school may be to group students into classes based on academic ability.

On the other hand, the phenomenon of cram schooling may be affected by the attributes of a school. Having cram schooling may be more popular for students at further academy-oriented schools, in comparison with students at a vocational school. However, some private schools noted for strict discipline may have offered students additional tutoring sessions, in addition to regular classes, in order that the percentage of students who participate in cram schooling may be lessened.

In other words, both between-class ability grouping and cram schooling may be presented as the results of "intrinsic" regional characteristics or school attributes, rather than being related to other factors, such as students' academic achievement or the economic background of students' family. Thus, the authors would like to revisit the relationships among ability grouping, cram schooling, and academic performance by bringing regional characteristics and school attributes back in. And the authors expect to provide different thoughts and reflections to relevant fields of education.

\section{LITERATURE REVIEW}

\section{The Meaning, Impacts, and Social Expectations of Between-Class Ability Grouping}

The general definition of between-class ability grouping is using different methods to group students, form a homogeneous class environment, and bring students with similar characteristics to study together (Huang 2008). In terms of reasons for between-class ability grouping, Gamoran et al. (1995) discussed between-class ability grouping from the perspectives of rationality and equality. They mentioned that, if a school is considered as an organization, between-class ability grouping is the organization's "rational response" to the heterogeneity of learners in this organization. Dividing learners into homogeneous groups can improve effective teaching and learning, as well as encourage students to learn from each other and collaborate. All these are positive benefits of between-class ability grouping.

However, it appears that between-class ability grouping is not necessarily fair from the perspective of equity, as students are not given equal opportunities (Hsieh and Yang 2003). In particular, different learning scenarios may result from teachers and schools' different teaching approaches and attitudes toward students with different abilities (Slavin 1990; Kulik 2004).

Many scholars focus on discussions regarding the interplay among between-class ability grouping, cultural capital, and social expectations. Initially, attention was paid to whether between-class ability 
grouping gives students from a family with higher socioeconomic status relatively advantaged learning environments and conditions (Gamoran 1986; Dreeben and Barr 1988; Rees, Brewer, and Argys 2000; Carbonaro 2005). Researchers also pointed out the symbolic implication hidden in the process of between-class ability grouping: Students with better ability also have parents or teachers who have higher expectations of them (Gamoran and Mare 1989; Zeidner and Schleyer 1999), whereas, it might be attributable to advantages brought about by cultural capital. Cultural capital refers to elements that are transferable from generation to generation, such as cultural background, knowledge, disposition, and skills (Bourdieu 1986). Other than being able to be internalized to mingle with a person's temperament and mind, and become habits, such as language, ability, behavior, habit, and taste in art, cultural capital is also observable in numerous institutionalized forms. For example, education background and social status may give parents different forms of capital and affect their involvement in their children's education, such as giving their children homework instructions and volunteering at schools (Broaded 1997; Cheung and Rudowicz 2003).

\section{Cram Schooling in Taiwan}

An understanding of the need for cram schooling and why cram schooling is so popular in Taiwan is a prerequisite for discussions. Liu (2006) conducted a study on the changes, effectiveness, and stratification of cram schooling in Taiwan, discussed the need for cram schooling, and reached a conclusion on the following two reasons. The first reason is the education reform of recent years. For many years, the biggest goal of education reform was to break the myth associated with further education and credentialism, alleviate students' pressure resulting from the pursuit of further education, diversify school curriculums, and bring teaching back to normal. Nevertheless, the implementation of various admission schemes and the
Nine-Year Consistent Curriculum (NCC) only increased students' need for cram schooling. The result of various admission schemes is that students participate in cram schools for learning talents or developing certain skills because students are worried that school teachers are not competent enough to teach courses in seven fields under the NCC. By attending a cram school, parents hope that their children could acquire knowledge from traditional courses, as well as engage in multidimensional learning through extracurricular classes.

Another reason for the prevalence of cram schooling in Taiwan is this society's changing demographic composition. In the course of demographic transition in Taiwan in recent years, the number of children in each family is falling, resulting in more concentrated family resources in comparison with families of previous generations. The concentration of educational resources has indirectly resulted in more students' cram schooling. After arranging causes for students' need for cram schooling, Liu (2012) also conducted a historical review of the development of the need of cram schooling, and concluded that relevant literatures could be classified according to three directions: "the profound impacts of credentialism", "the passing down and accumulation of cultural capital", and "the correlation among after-school tutoring, credentialism, and the labor market".

Other than reviewing the characteristics of cram schooling in Taiwan, the abovementioned statement clarifies the causes for the need for cram schooling, the influence on academic achievement, and puts forward on regional characteristics (Sun and Hwang 1996; Hwang and Chen 2005; Lin and Chen 2006; Hwang and Chen 2008; Lin and Huang 2009). However, all current studies have overlooked the role of school attributes. Whether a school is classified as an academy-oriented school or a vocational school makes a huge difference on students' cram school participation. Moreover, public and private schools 
show very distinct differences on the arrangement of additional tutoring sessions, in addition to regular classes for students, which might also affect the situation of students' cram school participation. As private schools in Taiwan can be classified as either "academy-oriented schools" or "non-academy-oriented schools", academy-oriented private schools usually have additional classes, which give students more comprehensive arrangements of additional tutoring sessions in addition to regular classes. Therefore, private school students have less need for after-school cram schooling. By contrast, most students in non-academy-oriented private schools are unable to get into a public school. The goal of most of these students is to earn a senior high school graduation certificate, thus, their motivation to study is not as strong, and therefore, they are less likely to go to cram schools. Therefore, this study would have further discussions on school attributes as a precondition of students' cram school participation.

\section{DATA AND RESEARCH METHODS}

\section{Quantitative Data Analysis}

The authors use the "Taiwan Education Panel Survey (TEPS)" to estimate the key variables on student achievement, and to verify the following research questions: To what extent is between-class ability grouping affected by regional characteristics? Are the situation and extent of students' cram school participation related to school attributes? What impacts do the two variables make on students' academic achievement?

As for the TEPS third-round questionnaire for senior high school and vocational high school students and their parents, a total of 20,079 students in 1,230 classes at 260 schools were interviewed. The 17,619 valid samples were collected after the questionnaires for students and the questionnaires for parents were consolidated and samples with illogical answers were picked out. The 17,619 valid samples consist of 8,588 male students (48.7\%), 9,031 female students (51.3\%); 11,440 public school students (64.9\%), 6,179 private school students (35.1\%); 1,276 rural area students (7.2\%), 6,278 town or village students (35.6\%), and 10,065 urban area students $(57.1 \%)$.

In the course of the operationalization of the variables, the authors chose senior high school students' marks at an analytical math skills exam and an integrated analytical skills exam during the interviews as indicators of the "academic achievement" variable. Independent variables in this study include: regional characteristics, school attributes, between-class ability grouping, and situations of cram school participation. Further, regional characteristics are classified as rural area characteristics, town and village characteristics, as well as urban area characteristics. School attributes are classified as public high school attributes and private high school attitudes. Considering that the classification on the original questionnaire was too detailed, the authors restructured the class grouping situation while students were in junior high school and divided grouping situations into three groups: "never in a good class before", "in a good class for some time", and "in a good class throughout the 3-year junior high school study". Moreover, students' cram school participation is assessed by the money and time which had been spent on cram schooling.

For the controlled variables, the authors have exercised control over students' socioeconomic status and students' self-expectation. The authors also include father's highest level of education, mother's highest level of education, and household monthly income into the socioeconomic status variable as well as convert parents' highest level of education to years of education received by parents. Students' self-expected highest level of education in the future is made a virtual variable in terms of students' self-expectation. However, the authors are unable to control endogenous factors which possibly result from 
between-class ability grouping while they were in junior high school as all follow-up samples in the database have never been placed in a good class and between-class ability grouping is this study's main independent variable. Nevertheless, as an analysis of interview data showed that most students only got accepted to a good class through influence peddling, results of the analysis still hold certain reference value.

\section{Qualitative In-depth Interview}

The authors interviewed five junior high school principals in Taichung and Kaohsiung's urban and rural areas and consulted their opinions about the current situation of schools' between-class ability grouping and students' participation in cram schools. Interview questions and answers were further transcribed for further analysis.

As the law specifically bans the practice of between-class ability grouping, the implementation of between-class ability grouping may not be direct and open. However, according to these school principals' observation, there are still situations when placement exams are used for within-class ability grouping or between-class ability grouping. High school principals stated that despite some parents' wish for having between-class ability grouping, relevant laws and regulations are quoted to turn their request down. However, ability grouping is still adopted for delivering a lecture to some students.

\section{EMPIRICAL RESULTS AND INTERVIEW FINDINGS}

\section{Quantitative Data Analyses}

First, the authors' results indicate that there are disparities in areas with different degrees of urbanization in terms of between-class ability grouping. According to the chi-square test, the degree of urbanization and situations of between-class ability grouping are not independent of each other.

Second, in terms of public and private school students' difference in cram school participation, the authors' results show the distinct difference. In particular, on average, a public school student spends more money and time on cram schooling than that of a private school student.

Third, private school students are less likely to participate in cram schools than those of public school students who have after-school classes. Urban area students are more likely to participate in cram schooling than those of students from rural area students.

Fourth, the authors' key variables do affect student achievement. Public school students' performance is better than private school students' performance; students in more urbanized areas perform better than rural area students; students with the experience of being in a good class perform better than students without the experience; and the effect of cram schooling on student achievement is significantly positive.

\section{Analysis of the Interview Contents}

First, the real between-class ability grouping situation varies among different areas. The practice of between-class ability grouping was quite prevalent in junior high schools in the past. At present, most schools opt for mixed-ability classes because of educational policies. Except for a small amount of students with exceptional exam marks at the time they graduate from primary school, most students get to be placed in a good class through influence peddling. Taking an interviewed school as an example, 3,000 students out of a total of 4,500 students are involved in influence peddling, the effectiveness of which may be related to the "importance" of those who are commissioned to carry out the influence peddling mission. Therefore, the mechanism of selection in between-class grouping may not be necessarily related to students' exam marks as how people imagine it. 
Second, between-class ability grouping does affect students' and teachers' self-expectation. Teachers who are assigned to teach a good class would act more diligently because they receive higher expectations from others. In addition to regular courses, teachers would hire out an off-campus venue for after-school tutoring. Driven by a pursuit for a higher proportion of students entering schools of a higher grade, schools usually turn a blind eye to teachers' after-school tutoring for students or even encourage teachers to do so. Therefore, good class teachers make more additional income. To give students after-school tutoring, some teachers only take three days off a year and go home very late every day. More diligent teachers of main subjects even work together to help students.

Third, in terms of academic achievement, between-class ability grouping gathers students with a more homogeneous ability level together. Therefore, it is fast to finish teaching the content on textbooks, students can acquire new knowledge fast, and many more supplementary teaching materials can be used, too. Giving students more extracurricular teaching materials and having many mock exams and tests are necessary for students' exams. Having similar-ability students in a class makes teaching easier for teachers. In a mixed-ability classroom, students' divergent ability levels make teaching more difficult and produce less effective results. Most interviewees are inclined to support between-class ability grouping as it leads to better academic achievement. "Education for everyone irrespective of the distinction of classes" can only be achieved by teaching students in accordance with their aptitude as the precondition.

Fourth, the social images of cram schooling and between-class ability grouping have changed over time. The practice of group instruction has been carried out in Taiwan for many years, yet many school principals and teachers still hold negative attitudes toward results of group instruction. On the one hand, group instruction makes it more inconvenient for schools to arrange course schedules and discipline students. On the other hand, group instruction's effects on students' academic study are limited when ability grouping largely focuses on main subjects such as Chinese, English, Physics, and Chemistry. Given such a circumstance, students' participation in group instruction and additional teaching sessions arranged by a school is falling. Because of this, the time students spend on cram schooling is increasing. Speaking of cram schooling, high school principals stressed that more than $80 \%$ of students have participated in cram schooling. Most students who do not participate in any cram schools have given up studying.

As revealed by these interview contents, the influence of family's socioeconomic background on whether students participate in cram schooling has been substantially slashed whereas students' self-perception about learning becomes important. The practice of between-class ability grouping may appear underhanded. Between-class grouping may have seemingly disappeared yet various actions are still active under the table.

\section{CONCLUSIONS}

Although between-class ability grouping and cram schooling are both longstanding phenomena in Taiwan's educational environment and have always received much attention, the academic world hardly delves into these issues from a school environment perspective. The authors argue that, as bringing regional characteristics and school attributes back in, the causal relationships among ability grouping, cram schooling, and student academic achievement can be analyzed more thoroughly.

According to the authors' quantitative data analyses and in-depth interview, between-class ability grouping and cram schooling do make significant impacts on academic achievement, and both the regional characteristics and school attributes also play 
important roles. The causal relationship among between-class ability grouping, cram schooling, and academic achievement calls for more studies to validate. Is it because between-class ability grouping affects academic achievement and subsequently affects cram schooling? Or does cram schooling affect academic achievement and cast an influence on between-class ability grouping? Only when we are clear about the internal mechanism among these variables can we present a more precise causal relationship among between-class ability grouping, after-school tutoring, and academic achievement.

\section{References}

Bourdieu, P. 1986. "The Forms of Capital." Pp. 241-260 in Handbook of Theory and Research for the Sociology of Education, edited by J. G. Richardson. New York: Greenwood Press.

Broaded, C. M. 1997. "The Limits and Possibilities of Tracking: Some Evidence From Taiwan." Sociology of Education 70:36-53.

Carbonaro, W. 2005. "Tracking Students' Effort and Academic Achievement." Sociology of Education 78(1):27-49.

Cheung, C. K. and E. Rudowicz. 2003. "Academic Outcomes of Ability Grouping Among Junior High School Students in Hong Kong." The Journal of Educational Research 96(4):241-254.

Dreeben, R. and R. Barr. 1988. "The Formation and Instruction of Ability Groups." American Journal of Education 97(1):34-64.

Gamoran, A. 1986. "Instructional and Institutional Effect of Ability Grouping." Sociology of Education 59:185-98.

Gamoran, A. and R. D. Mare. 1989. "Secondary School Tracking and Education Inequality: Compensation Reinforcement, or Neutrality?" American Journal of Sociology 94:1146-1183.

Gamoran, A., M. Nystrand, M. Berends, and P. C. LePore. 1995. "An Organizational Analysis of the Effects of Ability Grouping." American Educational Research Journal 32:687-715.

Hsieh, H.-C. and W.-B. Yang. 2003. "Longitudinal Study of Ability Grouping: Ability Grouping Fail to Educate According to Student's Aptitude." Humanity Education Journal 173:34-36.

Huang, M.-H. 2008. "Classroom Homogeneity, Family Background, and Math Performance: A Cross-National
Difference-in-Differences Analysis." Taiwanese Journal of Sociology 40:1-44.

Hwang, Y.-J. and C.-W. Chen. 2008. "Academic Cram Schooling, Academic Performance, and Opportunity of Entering Public Universities." Bulletin of Educational Research 54(1):117-149.

Hwang, Y.-J. and Y.-G. Chen. 2005. "The Problem of Entering Advanced Schools in Taiwan: A Review on Theory and Research of Sociology of Education." Taiwan Journal of Sociology of Education 5(1):77-118.

Kulik, J. A. 2004. "Grouping, Tracking, and De-tracking: Conclusions From Experimental, Correlation, and Ethnographical Research." Pp. 157-182 in Can Unlike Students Learn Together?, edited by H. J. Renolds and M. C. Wang. Greenwich, CT: Information Age.

Lin, C.-C. and T.-C. Huang. 2009. "Cram Culture." Journal of Social Sciences and Philosophy 21(4):587-643.

Lin, D.-S. and Y.-F. Chen. 2006. "Cram School Attendance and College Entrance Exam Scores of Senior High School Students in Taiwan." Bulletin of Educational Research 52(4):35-70.

Liu, J. 2006, "The Transition, Efficacy, and Stratification of Cram Schooling in Taiwan." Bulletin of Educational Research 52(4):1-33.

_. 2012. "Does Cram Schooling Matter? Who Goes to Cram Schools? Some Evidence From Taiwan." International Journal of Educational Development 32(1):46-52.

Rees, D. I., D. J. Brewer, and L. M. Argys. 2000. "How Should We Measure the Effect of Ability Grouping on Student Performance?" Economics of Education Review 19:17-20.

Slavin, R. E. 1990. "Ability Grouping and Student Achievement in Elementary Schools: A Best Evidence Synthesis." Review of Education Research 60:471-499.

Sun, C.-S. and Y.-J. Hwang. 1996. "Shadow Education, Cultural Capital, and Educational Attainment." Taiwanese Journal of Sociology 19:95-139.

Zeidner, M. and E. Schleyer. 1999. "The Effect of Educational Context on Individual Difference Variables, Self-perceptions of Giftedness, and School Attitudes in Gifted Adolescents." Journal of Youth and Adolescence 28:687-702.

\section{Bios}

Jeng Liu, Ph.D., professor, Department of Sociology, dean, College of Social Sciences, Tunghai University, Taiwan; research fields: sociology of education, quantitative methods.

Cheng-Hsiang Yang, Ph.D. student, Department of Sociology, Tunghai University, Taiwan; research fields: sociology of education, China studies. 